\title{
Some features of the hemostasis system in pregnant women at risk of developing preeclampsia
}

\author{
V.I. Chermak \\ Kiev Medical University
}

The objective: a study of the hemostasis system in pregnant women with a risk of preeclampsia development.

Materials and methods. 100 pregnant women with the risk for preeclampsia (main group) were examined. The risk factors were determined according to the Guideline "Hypertensive Disorders During Pregnancy", Order No. 676 of the Ministry of Health of Ukraine. The control group contained of 50 healthy women with physiological pregnancy. The groups were representative in age and reproductive history.

The following indicators of hemostasis were studied: the platelet system (the number of platelets, their aggregation ability and the total platelet aggregation index (TPAI), the coagulation system (autocoagulation test, thrombin time, prothrombin index, fibrinogen concentration) and the state of the fibrinolysis system which was determined by such indicators: plasma level of free heparin, activity of antithrombin III, indicators of ethanol and protamine sulfate tests, concentration of soluble fibrin in blood plasma.

Results. In pregnant women with a risk of preeclampsia, there are changes in platelet hemostasis indicators: a significant decrease in the number of platelets and a significant $(\mathrm{p}<0.05)$ increase in platelet aggregation ability, there is a tendency to an increase in TPAI indicators. In the main group a significant increase in the fibrinogen concentration, plasma lysis indicators and a tendency to an increase of the free heparin concentration, a decrease of antithrombin III and, in comparison with the indicators in healthy women, a 3 -fold increase in the content of soluble fibrin $(p<0.05)$ were found.

Conclusions. In pregnant women with a risk of preeclampsia development, there are disorders in the vascular-platelet hemostasis, coagulation and fibrinolytic blood systems, namely, a significant tension in the platelet link of the system, an increase in thrombogenic potential, and a sharp inhibition of the fibrinolytic link of hemostasis.

Keywords: pregnancy, preeclampsia, risk groups, hemostasis.

\section{Деякі особливості системи гемостазу у вагітних групи ризику розвитку прееклампсії B.I. Чермак}

\begin{abstract}
Мета дослідження: вивчення стану системи гемостазу у вагітних групи ризику розвитку прееклампсії.
Матеріали та методи. Обстежено 100 вагітних із групи ризику виникнення прееклампсії (основна група). Визначення факторів ризику проводили згідно з Протоколом «Гіпертензивні розлади під час вагітності», Наказ № 676 МО3 України. Контролем слугували дані обстеження 50 здорових жінок із фізіологічним перебігом вагітності системи (контрольна група). За показниками віку і репродуктивного анамнезу групи були репрезентативні.

Вивчено показники гемостазу: тромбоцитарної системи (кількість тромбоцитів, їхня агрегаційна спроможність та сумарний індекс агрегації тромбоцитів - CIAT), системи згортання (аутокоагуляційний тест, тромбіновий час, протромбіновий індекс, концентрація фібриногену) і стану системи фібринолізу, який визначали за такими показниками: плазмовий лізис, рівень вільного гепарину, активність антитромбіну III, показники етанолового і протамінсульфатного тестів, концентрація розчинного фібрину у плазмі крові.

Результати. У вагітних із групи ризику розвитку прееклампсії спостерігаються зміни показників тромбоцитарного гемостазу: достовірне зменшення кількості тромбоцитів і значне $(\mathrm{p}<0,05)$ підвищення агрегаційної спроможності тромбоцитів, відзначено тенденцію до збільшення показників CIAT. В основній групі вагітних встановлено достовірне підвищення концентрації фібриногену, показників плазмового лізису і тенденцію до зростання концентрацій вільного гепарину, зменшення антитромбіну III та, порівняно з показниками у здорових жінок, підвищення у 3 рази вмісту розчинного фібрину (р<0,05).

Заключення. У вагітних із групи ризику розвитку прееклампсії діагностують порушення у судинно-тромбоцитарному гемостазі, згортальній і фібринолітичній системах крові, а саме - значне напруження тромбоцитарної ланки системи, підвищення тромбогенного потенціалу, різке пригнічення фібринолітичної ланки гемостазу.

Ключові слова: вагітність, прееклампсія, групи ризику, гемостаз.

\section{Некоторые особенности системы гемостаза у беременных группы риска развития преэклампсии \\ В.И. Чермак}

Цель исследования: изучение состояния системы гемостаза у беременных группы риска развития преэклампсии. Материалы и методы. Обследовано 100 беременных из группы риска возникновения преэклампсии (основная группа). Определение факторов риска проводили согласно Протоколу «Гипертензивные расстройства во время беременности», Приказ № 676 Минздрава Украины. Контролем служили данные обследования 50 здоровых женщин с физиоло- 


\section{A K У Ш E P C T B O}

гическим течением беременности (контрольная группа). По показателям возраста и репродуктивного анамнеза группы были репрезентативны.

Изучены показатели гемостаза: тромбоцитарной системы (количество тромбоцитов, их агрегационная способность и суммарный индекс агрегации тромбоцитов - СИАТ), системы свертывания (аутокоагуляционный тест, тромбиновое время, протромбиновый индекс, концентрация фибриногена) и состояния системы фибринолиза, которое определяли по таким показателям: плазменный лизис, уровень свободного гепарина, активность антитромбина III, показатели этанолового и протаминсульфатного тестов, концентрация растворимого фибрина в плазме крови.

Pезультаты. У беременных из группы риска развития преэклампсии имеют место изменения показателей тромбоцитарного гемостаза: достоверное уменьшение количества тромбоцитов и значительное $($ р $<0,05)$ повышение агрегационной способности тромбоцитов, отмечена тенденция к увеличению показателей СИАТ. В основной группе беременных установлено достоверное повышение концентрации фибриногена, показателей плазменного лизиса и тенденцию к увеличению концентраций свободного гепарина, уменьшению антитромбина III и, по сравнению с показателями у здоровых женщин, повышение в 3 раза содержания растворимого фибрина $(\mathrm{p}<0,05)$.

Заключение. У беременных из группы риска развития преэклампсии имеют место нарушения в сосудисто-тромбоцитарном гемостазе, свертывающей и фибринолитической системах крови, а именно - значительное напряжение тромбоцитарного звена системы, повышение тромбогенного потенциала, резкое угнетение фибринолитического звена гемостаза.

Ключевые слова: беременность, преэклампсия, группь риска, гемостаз.

$\mathrm{P}^{\prime}$ reeclampsia is the most serious complication of pregnancy. It is known that preeclampsia is a genetically determined disease, which most often develops on the background of concomitant maternal extragenital pathology. The most important background for the preeclampsia occurrence is arterial hypertension and its first stage of development - somatotrophic dysfunction of the autonomic nervous system (SDA), or hypertensive type of vascular dystonia [1,2,3]. Gestosis on the background of hypertensive type of SDA occurs in 51-88\% of cases and is characterized by an earlier manifestation of all symptoms [4, 5, 6]. (V. Radzinsky et al., 2004).

The leading place in the etiopathogenesis of $\mathrm{PE}$ is given to the violation of adaptive reactions of the pregnant woman in response to the influence of endogenous and exogenous destabilizing factors (extragenital pathology, urogenital infection, chronic psychoemotional stress) $[7,8,9,10]$.

It is proved that pregnancy is accompanied by a complex of neuroendocrine changes that contribute to the formation of changes in blood flow in the microcirculatory tract, as well as changes in the hemostasis system. Physiological pregnancy is accompanied by a state of hypercoagulation due to an increase of $200 \%$ or more in coagulation factors against the background of reduced fibrinolytic and natural anticoagulant activity.

From the second trimester of pregnancy, the activity of procoagulants and platelets increases, the anticoagulant potential of the blood decreases. With the progression of pregnancy there is a significant increase in the concentration of fibrinogen in the blood (over 70\%), a decrease in APTT, which indicates an increase in the content of factors of the internal procoagulant chain of the hemostasis system: II, V, IX, X, XI, XII. An increase in PTI in late pregnancy indicates an increase in the activity of coagulation factors II, V, VII, X. An increase of the fibrin degradation products in the serum also indicates an intensification of intravascular coagulation processes [11, 12, 13].

According to the study results of the platelet part of the hemostasis system, it is proved that the aggregation activity of platelets practically does not change during pregnancy, the adhesion of platelets slightly increases $[14,15]$.

With increasing gestational age in healthy pregnant women, the hemostasis system changes in the direction of increasing blood clotting potential, namely - the rate of blood clotting increases and the structural properties of blood clotting strengthens, the content of PTI in serum increases in late pregnancy with a parallel increase in concentration I, II, VIII, IX, X, XII coagulation factors. The activity of factors XI (precursor of plasma thromboplastin) and XIII (fibrin stabilization) is reduced.

The high hemocoagulation potential of blood during pregnancy is associated with a decrease in its fibrinolytic activity. Changes in fibrinolytic activity of blood during pregnancy are caused by the influence of placental hormones (progesterone, placental lactogen) on the synthesis of fibrinolysis activators in the vascular endothelium. The number of platelets during pregnancy varies and depends on the degree of hemodilution and utilization of platelets in the placenta, as well as on the individual characteristics of the body. The level of fibrinogen (factor I) increases from 2.6 to $4-5 \mathrm{~g} / \mathrm{l}$, starting from the third month of pregnancy, and reaches maximum values on the eve of childbirth, which leads to an increase levels of degradation products and factors VII-X in blood [16, 17].

In the third trimester of pregnancy, and especially on the eve of the childbirth, a state of unstable equilibrium is formed between the blood clotting and fibrinolysis systems. The level of coagulation factors during pregnancy increases: factor I (fibrinogen) - almost 2 times, factors VII (proconvertin), VIII (antihemophilic factor), X (Stewart-Prauer factor) - by $50-100 \%$, factor II (prothrombin) - by $20-40 \%$. At the same time, fibrinolytic activity decreases due to changes in the circulating fibrinolysis proactivators activity, as well as with an increase in the level of fibrinolysis inhibitors. In addition, platelet aggregation abilities changes, which is a leading factor in the genesis of microcirculation disorders during pregnancy and childbirth $[1,8,16]$.

In addition, in the II-nd and especially in the IIIrd trimesters of pregnancy, the blood flow velocity in 


\section{A K У Ш E P C T B O}

the lower extremities veins is halved due to mechanical obstruction of the venous outflow tract, as well as a decrease in venous wall tone associated with hormonal changes during pregnancy.

At the end of the third trimester, the prothrombin index increases - the activation of the external blood clotting pathway. Fibrinolytic activity of plasma progressively decreases. The concentration of prothrombin (factor II) in early pregnancy does not change. The value of the prothrombin index in \% and INR (international normalized ratio) in pregnant women is $85-115 \%$ and $0.8-1.2$. The normal value of APTT in pregnant women is $28-38$ seconds. Indicators of factors V and XII, as well as bleeding time do not change during a normal pregnancy. The platelet count may decrease slightly. The normal value of platelets in pregnant women is $140-400 \times 10^{9} / 1$.

Thus, physiological hypercoagulation and blood stasis during pregnancy are ideal conditions for the development of thrombosis on the background of acquired or combined (acquired and genetic) thrombophilia.

During childbirth, all the mechanisms that help to prevent bleeding and increase the oxygen capacity of the blood are mobilized: the hematocrit increases, erythrocyte aggregation increases, and the blood's coagulation potential increases. The hemostatic potential of the blood and the adhesive activity of platelets increases, which helps to reduce blood loss during childbirth and in the postpartum period.

After childbirth, the body returns to a state of physiological hemodilution, the degree of which gradually decreases and which is aimed at maintaining blood flow in conditions of hypercoagulation and increased strength of erythrocyte aggregates.

Thus, the results of clinical-laboratory and clinical studies show that adaptive changes in the hemostasis system during certain periods of pregnancy should be considered in practical obstetrics, as they play an important role in the genesis of thrombohemorrhagic and thromboembolic complications in parturients and women in labor [18].

During late gestosis in pregnant women there is a constant activation of vascular-platelet and procoagulant chains of the hemostasis system, which leads to the development of DIC syndrome with a chronic course and a significant increase in the risk of venous thrombosis [19].

According to the results of research by $\mathrm{P}$. Chueva et al. (2002), a decompensated (thrombo-dangerous) type of hemostasis in late gestosis is found in $80.0 \%$ of patients, subcompensated - in $20.0 \%$ of subjects.

Thus, the level of fibrinogen degradation products in the blood increases on the background of changes in the quantitative and functional parameters of platelets, which forms a state of unstable equilibrium in the hemostasis system. In this situation, it is enough to join any adverse factor that provokes the hemostasis system (blood loss, surgical trauma, etc.) in order to bring this system out of balance.

The objective: to study the state of the hemostasis system in pregnant women at risk of developing preeclampsia.

\section{MATERIALS AND METHODS}

We examined 100 pregnant women from the risk group of this pregnancy complication (Main group). Determination of risk factors was performed according to the Protocol «Hypertensive disorders during pregnancy», Order № 676 of the Ministry of Health of Ukraine [3]. The survey data from 50 healthy women with physiological pregnancy (Control group) served as a control. The groups were representative in terms of age and reproductive history.

In the above patients, the indicators of all three links of hemostasis were studied: platelet (platelet count, their aggregation capacity and total platelet aggregation index (TPAI), coagulation system (autocoagulation test, thrombin time, prothrombin index, and fibrinogen concentration) and the state of fibrinolysis system, which was managed by the following indicators: plasma lysis, the level of free heparin, the activity of antithrombin III, ethanol and protamine sulfate tests, the concentration of soluble fibrin in blood plasma [18].

\section{RESULTS AND DISCUSSION}

Indicators of platelet hemostasis of the examined women are shown in table 1.

The results of the study of platelet hemostasis indicate a significant $(\mathrm{p}<0.05)$ decrease in platelet count $\left(188.9 \pm 11.3 \times 10^{3}\right.$ in the Control and $169.7 \pm 9.9 \times 10^{3}$ in the Main group) and a significant $(\mathrm{p}<0.05)$ increase of platelet aggregation capacity (respectively $30.9 \pm 4.1 \times 10^{3}$ and $41.8 \pm 4.5 \times 10^{3}$, respectively, in the Control and Main groups). TPAI indicators tended to increase. Analysis of the obtained indicators of vascular-platelet hemostasis indicates a significant tension of the platelet link of the hemostasis system in pregnant women at risk of developing preeclampsia.

Indicator's data of the coagulation system in examined patients are shown in table 2 .

Analysis of blood coagulation indicators indicates the absence of significant changes $(\mathrm{p}>0.05)$ in the indicators of the autocoagulation test $\mathrm{mA}(89.5 \pm 2.5 \%$ and $93.2 \pm 1.9 \%$, respectively, in the Control and Main groups) and ITA $1.6 \pm 0.1 \%$ and $1.7 \pm 0.2 \%$, respectively, in the Control and Main groups) between groups.

Indicators of platelet hemostasis in pregnant women at risk of preeclampsia, $\mathbf{M} \pm \mathbf{m}$

\begin{tabular}{|c|c|c|}
\hline The indicator under study & Control group $(\mathbf{n = 5 0 )}$ & Main group $(\mathbf{n = 1 0 0 )}$ \\
\hline Platelet count $\left(1 \times 10^{3}\right)$ & $188,9 \pm 11,3$ & $41,8 \pm 4,5^{\star}$ \\
\hline Platelet aggregation (\%) & $30,9 \pm 4,1$ & $41,1 \pm 2,9$ \\
\hline TPAI (\%) & $39,8 \pm 4,2$ & $\mathbf{4}$ \\
\hline
\end{tabular}

Note: ${ }^{\star}-\mathrm{p}<0.05$ between the indicators of the control and main group. 


\section{A K У Ш E P C T B O}

Table 2

Indicators of the blood coagulation system in the examined pregnant women, $M \pm m$

\begin{tabular}{|c|c|c|}
\hline The indicator under study & Control group, $\mathbf{n = 5 0}$ & Main group, $\mathbf{n = 1 0 0}$ \\
\hline Autocoagulation test: & & $93,2 \pm 1,9$ \\
- mA, \% & $89,5 \pm 2,5$ & $1,7 \pm 0,2$ \\
\hline - ITA (Index of thrombin inactivation) & $1,6 \pm 0,1$ & $11,2 \pm 0,5$ \\
\hline Thrombin time, sec & $10,3 \pm 0,4$ & $97,1 \pm 2,2$ \\
\hline Prothrombin index, \% & $99,1 \pm 3,5$ & $4,8 \pm 0,2^{\star}$ \\
\hline Fibrinogen, $\mathrm{g} / \mathrm{l}$ & $4,0 \pm 0,2$ & \\
\hline
\end{tabular}

Note: ${ }^{*}-p<0.05$ between the indicators of the control and main group.

Indicators of fibrinolysis in the examined patients, $M \pm m$

\begin{tabular}{|c|c|c|}
\hline The indicator under study & Control group, $\mathbf{n = 5 0}$ & Main group, $\mathbf{n = 1 0 0}$ \\
\hline Plasma lysis (mg/min-l) & $148,6 \pm 4,8$ & $1,4 \pm 0,4$ \\
\hline Free heparin (sec.) & $0,9 \pm 0,3$ & $56,4 \pm 3,2^{\star}$ \\
\hline Antithrombin-III (\%) & $65,6 \pm 1,1$ & $3,9 \pm 0,4$ \\
\hline Protamine sulfate test (mg\%) & $4,6 \pm 0,7$ & $2,9 \pm 0,4^{\star}$ \\
\hline Soluble fibrin (+) & $0,8 \pm 0,2$ & \\
\hline
\end{tabular}

Note: * $-p<0.05$ between the indicators of the control and main group.

Ethanol test values in the examined patients (\%)

Table 4

\begin{tabular}{|c|c|c|}
\hline The result of study & Control group, $\mathbf{n = 5 0}$ & Main group, $\mathbf{n = 1 0 0}$ \\
\hline Negative & 82 & - \\
\hline Weakly positive & 10 & 42 \\
\hline Positive & 8 & 58 \\
\hline
\end{tabular}

Note: ${ }^{*}-p<0.05$ between the indicators of the control and main group.

Thrombin time and prothrombin index do not differ $(p>0,05)$ and there is a significant difference $(p<0,05)$ in fibrinogen concentrations (from $4.0 \pm 0.2 \mathrm{~g} / \mathrm{l}$ in Control to $4.8 \pm 0,4 \mathrm{~g} / \mathrm{l}$ in the Main group).

Based on the obtained data, it can be assumed that the coagulation system in pregnant women at risk of preeclampsia is in a fairly compensated state, but a significant increase in fibrinogen concentration in pregnant women at risk of preeclampsia indicates an increase in thrombogenic potential of hemostasis in these patients.

Indicators of the fibrinolysis system in pregnant women at risk of preeclampsia are shown in table 3.

Analysis of the results of the pregnant women from the risk group of preeclampsia examination, indicates a significant $(\mathrm{p}<0,05)$ increase in plasma lysis (respectively $148.6 \pm 4.8$ and $227.3 \pm 12.6$ ) and a tendency to increase concentrations of free heparin, decrease of AT-III $(65.6 \pm 1.1 \%$ and $56.4 \pm 3.2)$, and, compared with healthy women, a 3 -fold increase in soluble fibrin from $0.8 \pm 0.2$ to $2.9 \pm 0.4(\mathrm{p}<0.05)$. Thus, it can be argued that the fibrinolytic component of hemostasis is sharply suppressed in pregnant women at risk of developing preeclampsia.

In addition, a positive reaction in the ethanol test was observed in $100 \%$ of pregnant women at risk of developing preeclampsia (table 4).

Thus, in pregnant women at risk of developing preeclampsia there is an increase in the thrombogenic po- tential of the hemostasis system by reducing the number of platelets and increasing their aggregation capacity, a significant increase in fibrinogen concentrations. The maximum coagulation stress of the hemostasis system in pregnant women at risk of preeclampsia is compensated by activation of the fibrinolysis system (increase in plasma lysis, increase in free heparin concentrations, 3 -fold increase in soluble fibrin, decrease in AT-III and 100\% positive ethanol test).

It should be noted that the unstable balance of the hemostasis system, which is observed in pregnant women at risk of preeclampsia, should be regarded as the first phase of thrombo-hemorrhagic syndrome (DIC).

Our results of the hemostasis system state in pregnant women at risk of developing preeclampsia indicate the feasibility of using drugs that have a positive effect on the state of the hemostasis system.

\section{CONCLUSIONS}

In pregnant women at risk of developing preeclampsia there are violations of the hemostasis system, with negative changes in all its parts: vascular-platelet hemostasis, coagulation and fibrinolytic systems.

The revealed violations can be considered as a pathogenetic substantiation of expediency to include the preparations with corrective influence on the system of a hemostasis in a complex of medical actions. 


\section{A K У Ш E P C T B O}

\section{Information about the author}

Chermak Vladimir I. - Kyiv Medical University, Academy of Human Health, Obstetrics and Gynecology, 02091, Kyiv, 121 Kharkivske Shose; tel.: (044) 564-21-65.E-mail:0509453723@ukr.net

\section{Відомості про автора}

Чермак Володимир Ігорович - Київський медичний університет, КНП «Академія здоров'я людини», акушерство та гінекологія, 02091, м. Київ, Харківське шосе, 121; тел.: (044) 564-21-65. E-mail: 0509453723@ukr.net

\section{Сведения об авторе}

Чермак Владимир Игоревич - Киевский медицинский университет, КНП «Академия здоровья человека», акушерство и гинекология, 02091, г. Киев, Харьковское шоссе, 121; тел.: (044) 564-21-65. E-mail: 0509453723@ ukr.net

1. Serov V.N. Preeclampsia. SPb.: Firm «Alina»;2011. 309 p.

2. Sidorova I.S. Preeclampsia in the focus of the doctor's attention is practice. Obstetrics and Gynecology. 2014;6:4-9. 3. High Risk Pregnancy: Evidence-Based Medicine Protocols. John T. Quinan, Catherine I. Spong, Charles J. Lockwood; transl. from English ed. HELL. Makatsaria, V.O. Bitsadze. M.: GEOTAR-Media; 2018. $560 \mathrm{p}$

4. Radzinsky V.E. Obstetric aggression. M.: Publishing house of the journal Status Presens; 2011. 688 p.

5. Emergency conditions in obstetric practice: a practical guide. A.Y. Senchuk, V.G. Ginzburg, I.I. Chermak and others; edited by prof. A. Senchuk. Kyiv: Phoenix; 2019. $336 \mathrm{p}$.

6. Sidorova I.S. Modern view of the problem of preeclampsia: arguments and facts. Obstetrics and Gynecology. 2013; 5: 10-6.

\section{REFERENCES}

7. Pregnancy, programming and preeclampsia: gap junctions at the nexus of pregnancy-induced adaptation of endothelial function and endothelial adaptive failure in PE. I.M. Bird, D.S. Boeldt, J. Krupp, M.A. Grummer, F.X. Yi, R.R. Magness. Curr Vasc Pharmacol. 2013 Sep;11(5):712-29.

8. Life-threatening conditions in obstetrics and perinatology. [V.O. Bitsadze, A.D. Makatsaria, A.N. Strizhakov. F. Chervenak]. Moscow: «Medical Information Agency»; 2019. 672 p. 9. Previtali E, Bucciarelli $P$, Passamonti S.M, Martinelli I. Risk factors for venous and arterial thrombosis. Blood Transfus. 2011 Apr; 9(2): 120-38.

10. Townsley D.M. Hematologic complications of pregnancy. Semin Hematol. 2013 Jul;50(3):222-31.

11. Mihu D, Razvan C, Malutan A, Mihaela $\mathrm{C}$. Evaluation of maternal systemic inflammatory response in preeclampsia. Taiwan J Obstet Gynecol. 2015 Apr;54(2):160-6.

12. Boeldt D.S, Bird I.M. Vascular adaptation in pregnancy and endothelial dysfunction in preeclampsia. J Endocrinol. 2017 Jan;232(1): 27-44.

13. Early pregnancy. From pregravid preparation to healthy gestation / Ed. V.E. Radzinsky, A.A. Orazmuradova. - 3rd ed., Rev. and add. M.: Editorial office of the journal Status Presens; 2018. $800 \mathrm{p}$.

14. Hansson S.R, Naav A, Erlandsson L. Oxidative stress in preeclampsia and the role of free fetal hemoglobin. Front Physiol. 2015 Jan 13;5:516.

15. Ventskovskaya I.B. Optimization of prevention of the onset and progression of gestosis. Women's health. 2013;7:365.

16. Lezhen T.I. Assessment of the equilibrium state between the coagulation and fibrinolytic blood systems in almost healthy people of different physiological states using the original express $\mathrm{mi}$ cromethod. Physiological journal. 1993;39(1): 24-8.

17. Senchuk A.Y. The state of the coagulation and fibrinolytic blood systems in pregnant women with iron deficiency anemia. Collection of Science Practices of Association of obstetricians and gynecologists of Ukraine. K.: «TMK»;1999, p. 145-7.

18. Senchuk A.Y. Determination of the state of hemostasis and fibrinolysis in pregnant women with iron deficiency anemia using the turbidimetric express micromethod. Actual problems of medicine and biology. Kiev; 1997, p. $90-100$

19. Preeclampsia foundation [Internet]. [cited 2017 June 1]. Available from: https://www.org/

\section{ПЕРЕВПЛАТА

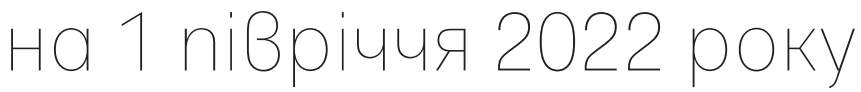

\section{5 вересня передплату можна оформити за «Каталогом видань України «Преса поштою»:}

- На сайті ДП «Преса» www.presa.ua

- На сайті АТ «Укрпошта» www.ukrposhta.ua

- У відділеннях поштового зв'язку

- В операційних залах поштамтів

- В пунктах приймання передплати

- В редакції видання

\section{Переgnnатний інgекс наукоВо-практичного Вияання «РепродуктиВне зgоров'я жінки»}

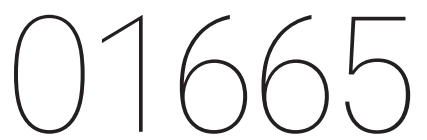

